\section{Jewish law}

\section{Science and the Jewish tradition}

THE current Jewish year, 5747 , is a sabbatical, not in the academic, but in the original sense of the word - the seventh year in which fields must be left unploughed and vines unpruned.This prescription, a valuable, but no longer valid early contribution to conservation policy, has been traditionally circumvented by symbolically selling the land on the eve of the sabbatical to a friendly Gentile, then "purchasing" it back as soon as the sabbatical is over. But a recent upsurge of fundamentalist "ultra-orthodoxy" in Israel has this year produced complications.

The politically potent ultra-orthodox object to wheat grown within the state of Israel being sold to flour mills and bakers. This could mean that the entire crop will have to be written off, with a massive subsidy to the farmers, although the government is trying to work out a compromise by which a limited amount of foreign wheat will be imported for use by bakers patronized by the ultra-orthodox.

The present controversy over the wheat highlights a problem which has faced the state of Israel from its inception 39 years ago. Although not technically a theocracy, state structures conform to the tenets of orthodox Judaism. In addition the state attempts to ensure that its citizens, whatever their degree of observance, have maximum facilities for fulfilling their religious duties as they see them.

This can lead to major confrontations, as when archaeologists, about to excavate a site, face the Talmudic prohibition on disturbing graves. More often the consequences are more amicable. Dr Rose Bilbul, a scientific entrepreneur who combines the commercial growing of papayas with research on the properties of papain, wished to sell her produce to a leading hotel. But the papaya, in spite of its appearance, is not, botanically speaking, a tree. The hotel insisted that expert advice be taken to assure that the appropriate blessing could be pronounced on the grove so that the hotel would be sure of maintaining its kosher kitchen.

Judaic law is essentially fixed, so scientific innovations pose challenging problems. Jewish law prohibiting cross-breeding and the production of chimaeras, for example, seems at first glance to rule out genetic engineering. But the rabbinic tradition has centuries of expertise in dealing with such situations, and ways have been found to permit such work to continue.

Israel has one institution specifically devoted to unravelling such problems, the Institute for the Study of Agriculture according to the Torah. The institute specializes in the development of biennial

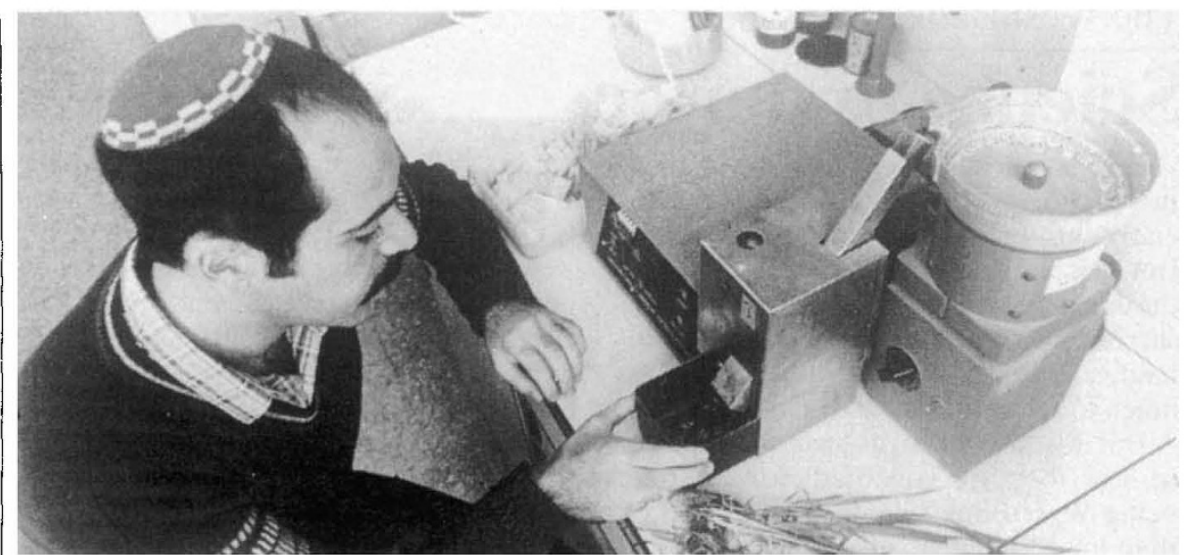

Graduate student Avraham Levy experiments with wheat grains.

crops that can be sown before and harvested after the sabbatical year.

Orthodox restrictions have spawned some ingenious devices. The prohibition against kindling a fire on the Sabbath (which is considered by the strict Orthodox to include switching on an electrical current) prompted domestic lighting sys-

tems which respond automatically to external twilight or darkness. The Sabbath telephone answers the phone automatically, placing the caller on hold. Since the connection is already established, the recipient of the call in picking up the receiver does not perform "work" in the Talmudic sense.

Vera Rich

\title{
A difficult transition
}

THE past twenty years have seen a major wave of Soviet immigrants to Israel. Though numbers fell to a few dozen per month in the pre-Gorbachev years, they never entirely dried up.

Jews make up a disproportionately large part of the Soviet scientific community. Although some Jewish scientists were temporarily or permanently refused an emigration visa on security grounds (the "refusniks"), and others simply used a visa for Israel as the first step to some other country (generally the United States), the influx of ex-Soviet scientists has been more than the Israeli scientific establishment could easily absorb. Yet the Law of Return guarantees any Jew repatriation in Israel, difficult as it might be to provide a suitable post for an incoming particle physicist or antarctic geologist.

The narrow specialization of Soviet higher education can make the transfer to some new speciality difficult. In some sense, the situation is less traumatic for a long-term refusnik, who is well aware that, in his years of waiting, he has fallen irrevocably behind with his professional reading, and who knows that his professional life in Israel must involve a new start. Resettlement is more complicated for the young engineer who arrives after a relatively short delay, only to find that his Soviet qualifications are too narrow, or simply not up to Western standards.

Over the years, various solutions have been proposed for the integration of refusnik scientists: a technology kibbutz in the Golan, endowed bridging grants for resettling, even the creation of fictitious one-man "departments" to cushion egos still attuned to a system where status is all important. Not all can make the psychological adjustment. Certainly, it is easier to absorb, say, a mathematician, who needs only a pencil and paper and desk than, say, an organic chemist or metallurgist who needs an expensive laboratory. And those who find room in the Israeli academic establishment have to adjust to a new way of working.

Israeli politicians and activists for aliya (immigration to Israel) state publicly that they will absorb any number of ex-Soviet scientists "even if it means wall-to-wall academics from Dan to Beersheva", as Golda Meir said at the Second World Conference for Soviet Jewry in 1976. But away from the rostrum, they have to face the reality that between Dan and Beersheva there are few posts for massive numbers of new researchers.

Last month, a Canadian all-party delegation visiting the Soviet Union on behalf of Soviet Jewry was given a broad hint that, if the West would cooperate with the Soviets on computer technology, the Soviet Union might lift the "security" restrictions on refusnik scientists. However much the Israelis might welcome such an agreement, there will still remain the problem of where to deploy the scientists so released. The best-known would undoubtedly be welcome elsewhere, especially in the United States. But after long years of waiting, it would be ironic if Israel could find them no appropriate job, even more ironic if those who have campaigned so long for their right to live as Jews in Israel should be obliged to take work elsewhere.

Vera Rich 